19. Savysko, V. M. (2009). Budivnyctvo elektrovoziv. Ukrai'ns'kyj naukovo-doslidnyj, proektnotehnologichnyj instytut (UHDПTI) [Electric locomotive building. Ukrainian Research, Design and Technological Institute (URDTI)] Encyclopedia of Modern Ukraine. Retrieved from http://esu. com.ua/search_articles.php?id=17734 (in Ukrainian).

20. Shatovsky, A. S., Volneansky, G. S. (1998). Rozhdennyj trizhdy. Kratkij ocherk istorii Dnepropetrovskogo jelektrovozostroitel'nogo zavoda. [Born three times. A brief outline of the history of the Dnepropetrovsk electric locomotive plant]. Dnepropetrovsk: RIO APDKT, $263 \mathrm{p}$. (in Russian).

Received 20.09.2020

Accepted 01.10.2020

\title{
М. Балишев
}

Центральний державний науково-технічний архів України, Харків, Украӥна

\section{АСТРОНОМІЯ В ХАРКОВІ У РОКИ ГРОМАДЯНСЫКОЇ ВІЙНИ ПЕРІОДУ УКРАЇНСЬКОЇ РЕВОЛЮЦІЇ (1917-1921)}

\author{
E-mail: m.a.balyshev@gmail.com
}

ORCID: https://orcid.org/0000-0001-5211-3208

Анотація. Розглянуто науково-дослідну діяльність астрономічної обсерваторії Харківського університету під час Української революції 1917-1921рр. Проаналізовано публікації харківських астрономів зазначеного періоду, присвячені фотометричним спостереженням зір, поглинанню світла та його відбиття від матових поверхонь, вивченню близькополюсних зір та зір типу бети Цефея, дослідженню Нової Орла 1918 та спостереженням планет. Автором застосовано спеціальні методи, використання яких дозволило виділити основні етапи розвитку астрономії у досліджуваному періоді, розкрити змістовність наукового потенціалу харківських астрономів. 3'ясовано біографічні відомості представників харківської астрономії та висвітлено їх участь у подіях громадянської війни. Висвітлено питання трансформації Харківської астрономічної обсерваторії на тлі перетворень Харківського університету у 1920-1921рр. Передбачається, що матеріали істориконаукового дослідження будуть використані в науково-дослідній роботі з історії астрономії у Харкові першої половини XX ст.

ключові слова: Харківська астрономічна обсерваторія (ХАО), громадянська війна, Українська революція, кафедра астрономії, астрономічний гурток, Харківський університет

\section{Balyshev}

Central State Scientific and Technical Archives of Ukraine, Kharkiv, Ukraine

\section{ASTRONOMY IN KHARKIV DURING THE CIVIL WAR PERIOD OF THE UKRAINIAN REVOLUTION (1917-1921)}

Abstract. As a result of the historiographical analysis, it was discovered that no separate publications were devoted to the study of the development of astronomical science in Kharkiv during the Ukrainian Revolution of 1917-1921. Therefore, the general purpose of the work is to study and synthesis facts of the history of Kharkiv astronomy in a certain period. The research activities 
of the astronomical observatory of Kharkiv University is considered, the personal composition of the observatory and the department of astronomy is clarified, the Kharkiv astronomers's publications of this period, devoted to photometric observation of stars, absorption of light and its reflection from matte surfaces, studying circumpolar stars and Beta Cephei starstype, exploration Nova Aquilae 1918, observation of the Moon and planets has also been analyzed. The author used special methods: historical-biographical, historical-chronological, retrospective and methods of source analysis, the use of which allowed to identify the main stages of astronomy in the studying period, to reveal the content of scientific potential of Kharkiv astronomers. The source base of the study included the materials of the archives of the Institute of Astronomy V. N. Karazin Kharkiv National University and the State Archives of Kharkiv region. Biographical information of representatives of Kharkiv astronomy and their participation in the events of the civil war has clarified, in particular: professors Ludwig Struve, Mykola Barabashov, Mykola Evdokimov, Vasiliy Fesenkov, Boris Gerasimovych, Otto Struve, astronomers Mykola Bobrovnikov, Volodymyr Mikhailov, Boris Semeykin. The issue of transformation of the Kharkiv Astronomical Observatory against the background of the turnings of Kharkiv University in 1920-1921 is covered. It is assumed that the materials of historical and scientific research will be used in research work on the history of astronomy in Kharkiv in the first half of the twentieth century.

Keywords: Kharkiv Astronomical Observatory, civil war, Ukrainian Revolution, Department of Astronomy, Astronomical club, Kharkiv University.

Вступ. За понад два століття астрономічна наука м. Харкова зазнала різних періодів свого існування: відкриття астрономічного кабінету в Харківському університеті у 1808 р. та створення астрономічної обсерваторії в Університетському саду (18831888); початок вивчення фізичних умов на Місяці та планетах та зародження планетної школи у 1930-х; тяжкі втрати часів Другої світової війни та відновлення матеріальнотехнічної бази наприкінці 1940-х; піднесення як планетного центру колишнього СРСР у 1950-х та міжнародне визнання з початком ери космічних досліджень. Пережила харківська астрономія і період революційної смути. Проведений історіографічний аналіз свідчить, що вивченню фактів з історії астрономії в Харкові під час громадянської війни періоду Української революції (1917-1921) не присвячено жодного історико-наукового дослідження. Навіть у фундаментальній праці «200 років астрономії в Харківському університеті» [13], в якій акумульовано історичні розвідки та напрацювання харківських астрономів та істориків астрономії, відповідному періоду майже не приділено уваги. Певні факти розвитку астрономічної науки та діяльності їі представників наведено в історичному нарисі «Астрономія в Харківському університеті за 150 років» [15], але видання 1955 р. має суцільне ідеологічне забарвлення, однобічно та упереджено висвітлюючи хід подій. Тому існує об'єктивна необхідність уточнення та узагальнення інформації з накопиченої у ході дослідження фактографічної бази про розвиток наукових студій в Астрономічній обсерваторії (AO) у визначений період, в т. ч. через вивчення біографічних відомостей харківських астрономів на тлі великих соціальних потрясінь.

Зважаючи на викладене, мета роботи - провести комплексне історико-наукове дослідження розвитку астрономії в Харкові у роки громадянської війни періоду Української революції (1917-1921) на прикладі Астрономічної обсерваторії Харківського університету.

Матеріал і методи досліджень. Застосовано спеціальні методи - історикобіографічний, історико-хронологічний, ретроспективний та методи джерелознавчого аналізу. Джерельну базу дослідження склали матеріали фондів архіву Науково-дослідного інституту астрономії ХНУ імені В. Н. Каразіна, Державного архіву Харківської області (фонд Р-5875) [2; 16].

Результати та обговорення. 1917-й в Харкові розпочався масовими страйками на підприємствах та вуличними демонстраціями робітників, які після подій Лютневої революції охопили все місто. Незважаючи на революційні настрої у суспільстві, університетська АО продовжувала працювати у звичайному режимі. Певні новації почалися з кадрових змін: 1 березня 1917 р. М. М. Свдокимова (1868-1941), який викладав основний курс астрономії в університеті, було призначено завідувачем АО. На 
цій посаді він змінив проф. Л. О. Струве (1858-1920), яку той обіймав упродовж майже чверті століття. Навесні проф. Струве було затверджено деканом фізико-математичного факультету Харківського університету. На плечі нового керівника АО повною мірою обрушився тягар адміністративного та господарчого управління у період революційного піднесення і громадянської війни. Упродовж найближчих років в АО опалення було відсутнім, інструменти (хронометри) зберігали в підвалах, де було трохи тепліше, ніж у робочих приміщеннях; огорожу і тротуари мешканці міста розбирали на опалення, навколо будівель обсерваторії почалася вирубка дерев з Університетського саду. Як наслідок - неогороджена територія навколо АО дозволяла вільний випас корів та кіз поміж павільйонами телескопів. Практично всі співробітники обсерваторії тяжко перехворіли. Зі звіту Харківського університету: «Працівники обсерваторії перебували у скрутному становищі внаслідок небезпеки і заборони пересування по вулицях навіть у ранні та нічні години. Неможливо було отримувати доброякісний та однорідний матеріал для фотографічних робіт ... Обсерваторія нерідко залишалася без освітлення і через брак палива температура в її приміщеннях опускалася до $-5^{\circ}$ » $[1$, с. 40].

У 1917 р. з обсерваторії звільнився В. В. Каврайський (1884-1954), у майбутньому відомий радянський астрометрист і картограф, який після закінчення університету у 1916 р. працював в АО обчислювачем. Б. П. Герасимовича (1889-1937), у майбутньому видатного астрофізика, директора Головної астрономічної обсерваторії (1933-1937), після повернення з Пулково призначено приват-доцентом Харківського університету та продовжено термін підготовки до професорського звання з астрономії [5, с. 116]. О. І. Сирокомського (1894-1961), у майбутньому відомого математика та директора астрономічної обсерваторії Львівського державного університету імені I. Франка (1945-1950), залишено в університеті для підготовки до професорського звання. В. Г. Фесенков (1889-1972), у майбутньому видатний астрофізик, академік АН СРСР, захистив дисертацію на звання магістра астрономії та геодезії на тему «Про природу Юпітера». В цій роботі Фесенков визначив показник прозорості атмосфери Юпітера, виклавши теорію його екваторіального прискорення, опис фізичних властивостей і особливостей планети [1, с. 21-22].

Наукова робота АО у 1917 р. зосередилася у таких напрямах: на меридіанному колі М. М. Свдокимов разом із обчислювачем І. О. Божко та асистентом К. Г. Гінце визначали поправки годинників. На початку року Євдокимов закінчив виміри фігури цапф, після їх обчислень дійшов висновку, що вони не дають таких похибок, які необхідно враховувати при обчисленні спостережень [1, с. 23]. Під керівництвом проф. Л. О. Струве К. Г. Гінце, І. О. Божко і допоміжні обчислювачі - студенти університету М. М. Душин, Я. Л. Геронімус та слухачки Вищих жіночих курсів О. Г. Гельд та П. Г. Пархоменко, здійснювали обробку меридіанних спостережень полярних зір, обчислювали прямі сходження зір і їх приведення до видимих місць, яке здійснювалося за оригінальним методом, розробленим К. Г. Гінце [1, с. 24]. Додамо, що М. М. Душин (1885-1930) та Я. Л. Геронімус (1898-1984), отримавши згодом наукові ступені та звання, у подальшому плідно працювали у харківських закладах вищої освіти у галузі математики, теоретичної та прикладної механіки; П. Г. Пархоменко (1896-1970), талановита учена-астрофізик, у 1920-1930-х працювала у Харківській та Симеїзькій астрономічних обсерваторіях [8].

Б. П. Герасимович досліджував світлофільтри Ф. Враттена і отримав понад 150 зображень змінної зорі RR Ліри. В. Г. Фесенков за допомогою фотометра Цельнера спостерігав зорі до 9-ї величини (кожну тричі, починаючи з осені 1916 р.); як результат, отримав 5440 оцінок яскравості. Влітку 1917 р. Фесенков здійснив фотометричні спостереження Місяця, але похмура погода завадила йому повноцінно спостерігати місячне затемнення [2].

Студенти фізико-математичного факультету Харківського університету займалися на обсерваторії, знайомлячись з інструментами і способами спостережень. Серед них найбільших успіхів досягли: М. П. Барабашов (1894-1971), у майбутньому відомий астроном-планетолог, директор Харківської астрономічної обсерваторії та академік 
АН УРСР, та І. М. Назаров (1892-1920), - через кілька років активний діяч у низці радянських урядів в Україні.

У 1917 р. на базі АО виник астрономічний гурток. За два роки його існування відбулося 18 засідань, на яких обговорювалися доповіді спеціального і популярного характеру, здійснювалися спостереження неба і проводилися екскурсії на університетській та «аматорській» обсерваторіях. Студенти-астрономи М. П. Барабашов та I. М. Назаров стали ініціаторами та активними діячами цього гуртка. Зокрема, Назаров, який був членом партії більшовиків та одним з перших комуністів Харкова, використовував астрономічний гурток і для політичної агітації, оскільки у його засіданнях брали участь не тільки студенти Харківського університету, але й демократично налаштована харківська молодь. [14, с. 22-23].

У 1917 р. публікації харківських астрономів обіймали такі теми: Барабашов опублікував спостереження Юпітера і сонячних плям; Фесенков підготував низку публікацій, присвячених природі Юпітера і визначенню показника прозорості його атмосфери, дослідження про походження місячних форм рельєфу та результати спостережень змінної зорі 55 Орла. Окремо слід вказати на статтю «Про відбиття світла матовими поверхнями», в якій Фесенков розглядав задачу розсіювання світла в розрідженій атмосфері частинок у наближенні двократного розсіювання (узагальнення закону Ломмеля-Зеєлігера, пізніше відоме як наближення Шенберга [13, с. 85].

В лютому-березні 1918 р. почалася німецько-австрійська інтервенція в Україні, на початку квітня було захоплено Харків. На тлі цих подій у Харківському університеті вперше в країні до обов'язкових університетських предметів було введено курс астрофізики, читання якого розпочав В. Г. Фесенков. Навесні з фронтів Першої світової війни до Харкова повернувся О. Л. Струве (1897-1963), у майбутньому всесвітньо відомий американський астрофізик і організатор науки, директор Єркської та Макдоналдської обсерваторій (США), президент Міжнародного астрономічного союзу (1952-1955). Він почав працювати у школі-майстерні точної механіки при АО, продовживши навчання в Харківському університеті, яке перервав у зв'язку із рішенням піти на фронт. Використовуючи прилад Мессера, Струве вимірював фотографії часткової фази сонячного затемнення 1914 р., отримані у Генічеську експедицією харківських астрономів, в якій він брав участь [6, с. 29-30].

У 1918 р. наукова робота харківських астрономів зосередилася переважно на дослідженні Нової зорі, яка спалахнула у сузір'ї Орла влітку: К. Г. Гінце на меридіанному колі провів серію спостережень та визначив ії положення; проф. М. М. Євдокимов 3 червня по жовтень фотографував Нову Орла, використовуючи зелені та червоні фільтри; Б. П. Герасимович та В. Г. Фесенков також спостерігали цю зорю, зокрема останній зробив 2616 оцінок іiі яскравості (оброблення цих спостережень було завершено у 1919 р.). Обчислювальна робота, яка проводилася проф. Л. О. Струве, К. Г. Гінце, I. О. Божко, Б. П. Герасимовичем та О. Г. Гельд, зосередилася на обробці спостережень полярних зір [1, с. 39].

Упродовж року Б. П. Герасимович фотографував туманність Оріона, обробив платівки з понад 200-ма зображеннями зорі RR Ліри, відзнятими упродовж 19161917 pp., отримавши швидко мінливу криву яскравості. В. Г. Фесенков за допомогою фотометра Цельнера продовжував спостерігати близькополюсні зорі (виконав 8288 оцінок яскравості, паралельно виконував обробку спостережень). Саме він запропонував студенту М. П. Барабашову, який працював над дипломом, спробувати вирішити завдання щодо відбивної здатності Землі (визначити відношення кількості світла, відбитого планетою в усіх напрямках, до кількості світла, що впало на неї від Сонця). Фесенков проводив спостереження над світінням нічного неба, вивчаючи залежність даного світіння від зенітної відстані, досліджував проблему спостереження сутінків і будови стратосфери до висоти в 150 км [1, с. 38-39].

Зазначимо, що в цей період у процесі здійснення спостережень Місяця Барабашовим було відкрито явище, яке пізніше стало відоме як «ефект Барабашова-Маркова». Воно полягало в тому, що кожна ділянка місячної поверхні досягає максимальної 
яскравості лише коли кут падіння і кут відбиття світла практично дорівнюють один одному, перебуваючи по одній стороні від нормалі, а не під час прямовисно падаючих променів [15, с. 78].

Серед публікацій харківських астрономів 1918 р. слід зазначити статті Б. П. Герасимовича $з$ дослідженню різних характеристик зір типу дельти Цефея (показників світла, щільності, визначення діаметрів), вивчення абсолютних величин гелієвих зір та коливання газової кулі; та В. Г. Фесенкова, в яких астроном зосередився на вивченні поглинання світла у світовому просторі та спостереженнях над сутінками і будовою атмосфери $[1$, с. 38-39].

У ніч 317 на 18 листопада 1918 р. у Харкові запанувала влада Директорії, у перші дні 1919 р. до міста увійшли війська Червоної Армії. Всеосяжне руйнування в місті підсилилося через воєнні події взимку 1919 р., становище АО суттєво погіршилося, спостереження практично зупинилися: холод і часті перерви в електропостачанні вивели з ладу акумулятори, головний годинник обсерваторії кілька разів зупинявся, інструменти не ремонтувалися. Та все ж у 1919 р. АО завершила основний етап багаторічної роботи щодо спостережень полярних зір: складено їх попередній каталог. М. П. Барабашов спостерігав зміни яскравості Нової Орла 1918 та за допомогою візуального фотометра продовжував роботу з визначення альбедо земної кулі [13, с. 392].

В. Г. Фесенков здійснював системні фотометричні спостереження: за період 19161919 рр. він виконав 1115 спостережень зір, розташованих в межах $11^{\circ}$ по схиленню від північного полюса світу. Вони і склали основу фотометричного каталога, виданого у 1926 р. В цей період науковець формує уявлення про спільне створення нашої планетної системи і Сонця, яке, зокрема, розглядалося в публікації «Щодо моменту кількості руху Сонячної системи з точки зору космогонічної гіпотези Лапласа» [12].

Події громадянської війни упродовж 1919 р. вплинули на особисті долі харківських астрономів, роз'єднавши їх за політичними поглядами. Цього року Харківський університет залишився напівпорожнім: більша частина студентів вступила до лав Добровольчої армії, інші воювали на боці Червоної армії. М. П. Барабашов після встановлення в Харкові радянської влади розпочав активну науково-пропагандистську роботу. Упродовж 1917-1918 pр., як лектор Губполітпросвіту, він виступав з науковопопулярними лекціями з астрономії, антирелігійного характеру, в т. ч. про можливість здійснення міжпланетних подорожей. У 1919-1920рр. подібні виступи Барабашов влаштовував у казармах та шпиталях перед червоноармійцями та комсомольцями. Швидко зростає політична кар'єра у різних структурах радянської влади I. М. Назарова. Про настрої, що вирували в університетському середовищі, йдеться у статті професора фізмату Т. П. Кравця (1876-1955): «... зі вступом до Харкова радянських військ тут же утворилася і рада народних комісарів. Портфель комісара Народної освіти дістався якомусь В. Затонському, колишньому асистенту фізичної лабораторії Київського політехнікуму... Здебільшого всім експериментам над школою ми зобов'язані його безпосередньому помічникові I. М. Назарову, який за рік перед тим закінчив курс Харківського університету (спеціально цікавився астрономією) і вже відігравав певну роль в уряді «Донецько-Криворізької республіки». Вважаємо своїм обов'язком зберегти для потомства ім'я цього видатного обскуранта...» [7, с. 27]. Зауважимо, що I. М. Назаров загинув у бою під Києвом у 1920 р.

У перші дні 1919 р., керуючись особистими переконаннями, до лав Другого Дроздовського полку Добровольчої армії генерала В. З. Май-Маєвського вступив студент-астроном фізмату Харківського університету М. Ф. Бобровников (1896-1988), у майбутньому відомий своїми роботами у галузі вивчення спектрів і фотометрії комет американський астроном, директор Перкінсівської обсерваторії (1937-1951). Всю війну М. Ф. Бобровников пройшов у званні поручика. У своїх щоденниках, які вів під час війни, він зазначав: «...Я просто усвідомив, що боротьба з комуністами $\epsilon$ моїм обов'язком... Вступаючи в Добровольчу армію без особливого ентузіазму, я особливо був стурбований моторошним станом їі моралі. Для більшості наших офіцерів Добровольча армія виявилася лише притулком від комуністичного терору. 
Коли людей загнано в кут і методично знищують, їм вже нічого не залишається, як чинити спротив...» [3, с. 43$]$.

Отримавши у бою важке поранення у травні 1919 р., він провів півроку в армійських шпиталях. Навесні 1920 р. серед багатьох інших поранених і хворих евакуюється англійським військовим транспортом на о. Кіпр. Восени 1921 р. через Грецію М.Ф. Бобровников перебрався до Королівства сербів, хорватів і словенців і вже в жовтні 1921 р. став студентом університету в Любляні. Через місяць - опинився у Чехії, виконавши звичайний для того часу маршрут російського біженця... У 1924 р. емігрує до США [3, с. 44].

Вночі 11 (24) червня 1919 р. в Харків без бою увійшли перші загони Добровольчої армії генерала В. 3. Май-Маєвського. У перші ж дні до армії записалася маса харківських добровольців. Серед них був О. Л. Струве, офіцер-артилерист, який отримав бойове хрещення на Турецькому фронті. Через півстоліття, згадуючи ті дні, він напише: «... я вважав свою участь в громадянській війні найбільшим актом самопожертви. Я не маю сумнівів, що прийде час, хоча, можливо, і не за мого життя, коли росіяни зрозуміють, що патріотизм не був ексклюзивним привілеєм тих, хто боровся на стороні, яка перемогла...» [5, с. 142]. Саме ці обставини змусили проф. Л. О. Струве залишити університет і обсерваторію в жовтні 1919 р. і терміново переїхати до Криму. Колеги проф. Струве, які також опинилися у Сімферополі, писали: «...Абсолютно зрозуміло, що при відступі з Харкова [Добровольчих військ - М. Б.], старий професор не міг залишитися в «червоному» університеті і пішов, кинувши свою цінну бібліотеку і обсерваторію...» [13, с. 105]. У Криму проф. Л. О. Струве продовжував педагогічну і наукову діяльність в Таврійському університеті, очоливши кафедру астрономії. Разом із старшим сином Отто, який також опинився у Криму, вони продовжували вивчення змінних зір, зокрема у серпні 1920 р. спостерігали Нову у сузір'ї Лебедя. Проф. Л. О. Струве помер у листопаді 1920 р. у Сімферополі під час відкриття 3’їду Таврійської наукової асоціації [13, с. 106].

В липні 1919 р. О. Л. Струве, який воював у складі першого корпусу Дроздовської артилерійської бригади, був поранений під селом Головніно (Курської губернії). Провівши два тижні в госпіталі, у серпні 1919 р. він знову в строю. Але безпосередньої участі в боях уже не брав (очевидно, внаслідок отриманої контузії). Відступаючи з важкими боями у складі 3-ї піхотної офіцерської дивізії генерал-майора М. Г. Дроздовського, у березні 1920-го О. Л. Струве опинився на Кавказі, в районі Новоросійська. Пізніше військові дороги привели його до Севастополя. У листопаді 1920 р. військові кораблі під прапорами держав Антанти починають евакуацію з Криму: переважно, транспорти прямували до Константинополя. На одному з них О. Л. Струве було евакуйовано до Туреччини. Зиму 1920-1921рp. Струве провів у військовому таборі в Галліполі; восени 1921 р., отримавши запрошення від директора Сркської обсерваторії Е. Б. Фроста 3 пропозицією посади асистента по зоряній спектроскопії, О. Л. Струве емігрував до США [5, с. 142-143].

Після термінового від’їзду у Крим проф. Л. О. Струве на початку листопада 1919 р. проф. М. М. Свдокимов також звернувся до ректорату Харківського університету 3 проханням надати відпустку для виїзду до Ростова-на-Дону «за домашніми обставинами». Таким чином, Свдокимова офіційно було відряджено Харківським університетом на Кавказ та Крим. Згідно з поясненнями М. М. Свдокимова, які він надав після повернення до Харкова, зважаючи на активні військові дії, які розпочалися навесні 1920 р. у Краснодарі, він опинився у П'ятигорську, де захворів на пневмонію. За медичними документами, Свдокимов проходив тривале лікування у Кисловодську. Після його повернення до Харкова в серпні 1920 р. відділення В.Н.З. Наркомпросу, розглянувши пояснення та надані документи, відновило проф. М. М. Свдокимова на викладацькій роботі [5, с. 111].

У листопаді 1919 р. було оголошено нову загальну мобілізацію «...для поповнення частин Добровольчої армії і з метою рівномірного розподілу тяготи військової повинності...» [5, с. 133]. Після закінчення університету (в цьому році) М. П. Барабашов 
був залишений при кафедрі астрономії для «приготування до професорського звання» (навчався в аспірантурі без права отримання стипендії). За архівними документами, мобілізації він не підлягав через незадовільний стан здоров'я [16, арк. 18]. Але уникнути призову не вдалося двом майбутнім астрономам XАО, на той час випускникам гімназій В. О. Михайлову (1901-1955) та Б. С. Сємейкіну (1900-1938).

Зокрема, майбутнього астрометриста В.О. Михайлова, який в роки німецької окупації Харкова періоду Другої світової війни (1941-1943) зробить особистий подвиг врятує обсерваторські інструменти, бібліотеку та архів, мобілізовано у «глибокий» тил: був відряджений до штату запасного шпиталю в Сімферополі на посаду дезінфектора. Але радість від того, що вдалося уникнути передової лінії фронту, швидко змінилася жахом військових буднів: лютували інфекційні захворювання; у шпиталі щодня вмирало багато людей. Робота із хворими та сильними отрутохімікатами швидко позначилася на здоров’ї В. О. Михайлова [5, с. 133]. Наприкінці жовтня 1920 р. після захоплення шпиталю Червоною Армією та розстрілу медперсоналу Михайлова серед небагатьох, яких залишили в живих, знову перезарахували до штату Сімферопольського військового шпиталю, але вже Червоної Армії. Припускаємо, що об'єктивною причиною порятунку була специфіка його роботи: необхідно було провести ретельне поховання загиблих, перешкоджаючи поширенню інфекційних хвороб (холери і тифу). Цей кошмар тривав упродовж десяти місяців до серпня 1921 р., коли В. О. Михайлов, червоноармієцьдезінфектор, виконував одну з найбрудніших робіт військового часу [5, с. 134].

Б. С. Сємейкін - у недалекому майбутньому талановитий астроном, наукова діяльність якого була присвячена планетним дослідженням. У 1930-ті він брав участь у серії спектрофотометричних спостережень Місяця, Марса, Юпітера і Сатурна, одним 3 перших розпочав спостереження на спектрогеліоскопі (спектрогеліографі) XАO, в т. ч. за програмами міжнародної Служби Сонця. Ім'ям Сємейкіна названо кратер на Марсі [4]. Влітку 1919 р. він вступив рядовим у Добровольчу армію. Менше ніж через рік військові дороги і колізії долі приведуть його до лав Червоної армії, розділивши в цій частині долю свого майбутнього колеги по ХАО В. О. Михайлова. У 1938 р. Б. Є. Сємейкін трагічно загине у катівнях НКВС: одним з пунктів обвинувачення стане його служба у Добровольчій армії [4, с. 74].

Влітку 1920 р. Харківський університет було перетворено в Академію теоретичних знань, через рік - у Харківський Інститут народної освіти (ХIHO). Зазнала структурних змін і Астрономічна обсерваторія, на базі якої була створена науково-дослідницька кафедра астрономії ХІНО. У цей період перетворень М. М. Свдокимов виконував обов’язки декана «зведеного ліквідаційного курсу фізико-математичного та історикофілологічного факультетів» [5, с. 111].

М. П. Барабашов спостерігав Марс за допомогою власноруч виготовленого 10 $1 / 2$ дюймового рефлектора; відновилися спостереження змінних зір, сонячних плям, Місяця і планет. У цьому році В. Г. Фесенков з родиною переїхав до Новочеркаська, де його обрали завідувачем кафедри теоретичної механіки Донського політехнічного інституту і кафедри астрономії Донського педінституту. Але він часто наїжджав до Харкова, беручи участь у науковій роботі ХАО [11, с. 53]. Фесенков завершив підготовку докторської дисертації і представив ії на фізико-математичному факультеті Харківського університету. Але її захист не відбувся через скасування вчених ступенів [15, с. 81]. 3 листопада 1920 р. Б. П. Герасимович зосередився на викладацькій діяльності (читав курси астрономії, механіки, аеродинаміки) у різних закладах освіти міста, поєднуючи iii 3 посадою старшого астронома ХАО [5, с. 116].

У 1921 р. наукову роботу харківських астрономів фактично було зведено до мінімуму: у квітні в ХАО вивчали кільцеподібне затемнення Сонця, яке фотографували за допомогою дводюймової труби Долонда; у жовтні - М. М. Євдокимов з М. П. Барабашовим спостерігали часткове місячне затемнення; фотографували спектри зорь через фільтри; К. Г. Гінце займався визначенням часу та обробкою спостережень зодіакальних зір. Серед публікацій ХАО 1921-го слід вказати на декілька популярних брошур М. М. Свдокимова, Б. П. Герасимовича та статті М. П. Барабашова, присвячені аналізу світла Венери та фотометричним дослідженням яскравості нічного неба [13, с. 392]. 
Восени 1921 р. в Харкові по відділенню фізико-математичних наук були організовані вісім кафедр, серед яких була кафедра астрономії, яка спочатку мала лише два відділення: астрономії і метеорології. Завідувачем кафедри призначено проф. М. М. Свдокимова. Він клопотав перед Наркомпросом УРСР про те, що на ХАО є умови для створення астрофізичного відділення, яке може використовувати ресурси, інструменти та приміщення астрометричного. Таким чином, завідувач ХАО пропонував розширити iii штат, включивши в нього трьох професорів (старших астрономів), трьох ад'юнктів, трьох асистентів і трьох обчислювачів, механіка 3 помічником і декількох служителів. Але фактично штат обсерваторії в цей час складався із завідувача М. М. Свдокимова, викладача і магістра В. Г. Фесенкова, викладача К. Г. Гінце, астронома Й. Сикори (18701944), який повернувся до Харкова з Єкатеринбурга, М.П. Барабашова та двох технічних працівників [15, с. 69]. Наукова робота обсерваторії за планом М. М. Свдокимова в найближчі роки повинна була зосередитися на астрометричній тематиці та організації робіт геодезичного характеру [15, с. 78-79].

В результаті Наркомпросом УРСР було затверджено кафедру у складі чотирьох секцій: астрометрії з геодезією (завідувач проф. М. М. Євдокимов), астромеханіки, астрофізики (обома завідував В. Г. Фесенков) та геофізики (метеорології) (завідувач проф. Д. К. Педаєв (1873-1936). План наукової діяльності кафедри зосередився, з одного боку, на роботах теоретичного характеру, з іншого - був спрямований на обробку значного масиву спостережного матеріалу, акумульованого ХАО, та здійсненяі нових спостережень [2]. 3 утворенням ХІНО у 1921 р. посади обчислювачів, як невикладацькі, були скасовані. Як наслідок, ХАО було позбавлено посад спостерігача, обчислювачів і механіка. М. М. Євдокимов пригадував, що упродовж кількох місяців обсерваторія залишалася без необхідного для поточних робіт щорічника. Це унеможливлювало проведення масштабних спостережних робіт [15, с. 72].

Поступово країна виходила з руїни громадянської війни, відновлювалися фахові контакти, проводилися наукові з'їзди. Зокрема, у вересні 1921 р. відбувся Перший Всеросійський з'їд любителів світознавства. Від Харківської астрономічної обсерваторії в ньому взяв участь М. П. Барабашов, якого було обрано до президії у якості голови астрономічної секції [9]. Але побутові умови в XАО знову погіршилися: майже постійна відсутність електрики, водопровід пошкоджено, температура у приміщеннях дуже низька, оскільки не було опалення, співробітники масово хворіли. Наприклад, на засідання кафедри астрономії 01 грудня 1921 р. зібралися лише М. М. Євдокимов, Б. П. Герасимович та М. П. Барабашов, але працювати у приміщенні з температурою $-1,5^{\circ}$ було неможливо, тому було вирішено збиратися у Євдокимова вдома. Наприкінці грудня температура в приміщеннях ХАО знизилася до $-3^{\circ}$, всі обсерваторські годинники зупинилися... [2].

Лише у 1922 р. ХАО почала повертатися до стабільного функціонування та сталої наукової роботи. Незабаром тут буде розпочато важливі меридіанні спостереження схилення зір абсолютним методом (в т. ч. великих планет), спостереження зір КопфаРенца за програмою Міжнародного астрономічного союзу, дослідження фізичних умов на Місяці та планетах. У цей рік також суттєво оновився колектив кафедри астрономії: В. Г. Фесенков почав працювати на посаді директора Головного астрофізичного інституту у Москві [11, с. 54], астроном Й. Сикора виїхав до Чехії, де викладав у Карловому університеті [10]; викладач К. Г. Гінце та астроном І. О. Божко померли від туберкульозу [2]; на кафедрі почали працювати проф. С. М. Семілєтов (1879-1943) та науковий співробітник О. М. Панов (1869-1926) [15, с. 71]; системні зайняття на обсерваторії розпочали В. О. Михайлов та Б. Є. Сємейкін, які після демобілізації з армії почали навчатися на факультеті профосвіти (фізико-математичне відділення) XIHO [4, с. 72; 5, c. 134].

Висновки. Досліджено історію астрономії в Харкові у період 1917-1921 рр. на прикладі Харківської астрономічної обсерваторії. Проаналізовано науково-дослідну роботу ХАО, розглянуто публікації харківських астрономів цього періоду, наведено біографічні відомості з висвітленням фактів про участь представників харківської 
астрономії у подіях громадянської війни. В подальшому передбачається, що матеріали історико-наукового дослідження розвитку астрономії в Харкові періоду Української революції будуть використані в науково-дослідній роботі, присвяченій історії астрономії у Харкові першої половини XX ст.

\section{REFERENCES}

1. Kratkij otchet o dejatel'nosti Har'kovskogo universiteta v 1917-1918 gg. [Abridged report on the activities of Kharkov University in 1917-1918]. Zapiski Har'kovskogo universiteta za 1918 i 1919 gg. Har'kov, 1919, 1-62 (in Russian).

2. Arhiv Instituta astronomii Har'kovskogo nacional'nogo universiteta im. V. N. Karazina (1917-1922) (in Russian).

3. Balyshev, M. A. (2008). Astronom Nikolaj Fedorovich Bobrovnikov [Astronomer Nikolai Fedorovich Bobrovnikov]. Universitates. Nauka i prosveshhenie, 1, $42-49$ (in Russian).

4. Balyshev, M. A. (2018). Istoriko-biograficheskij ocherk zhizni i nauchnoj dejatel'nosti Borisa Semejkina (1900-1938) [A Historical and Biographical Study of the Life and Scientific Work of Boris Semeykin (1900-1938)]. Kinematika i fizika nebesnyh tel, 34 (2), 71-75 (in Russian).

5. Balyshev, M. A. (2008). Iz istorii Har'kovskoj observatorii: Biograficheskie ocherki [From the history of the Kharkiv Observatory: Biographical Essays]. V: Shkuratov Ju. G. (red.) 200 let astronomii v Har'kovskom universitete. Har'kov: Har'kovskij nacional'nyj universitet, 99-154 (in Russian).

6. Balyshev, M. A. (2008). Otto Ljudvigovich Struve (1897-1963) [Otto Ludwigovich Struve (1897-1963)]. Moskva: Nauka, 524 s. (in Russian).

7. Balyshev, M. A. (2005). Professor istorii Mihail Vasil'evich Klochkov. Dokumental'nobiograficheskoe issledovanie [Professor of History Mikhail Vasil'evich Klochkov. Documentally and biographical research]. Universitates. Nauka i prosveshhenie, 2, 18-29 (in Russian).

8. Balyshev, M. A. (2018). Istoriko-biograficheskoe issledovanie zhizni i tvorchestva ukrainskogo astronoma Praskov'i Georgievny Parzomenko [Historical and biographical study of the life and work of the Ukrainian astronomer Praskovya Georgievna Parkhomenko]. Nauka i naukoznavstvo, 1, 114-137 (in Russian).

9. Barabashov, N. P. (1921). O ljubiteljah astronomii v Har'kove [On amateurs of astronomy in Kharkov]. V sb. Pervogo Rossijskogo s\#ezda ljubitelej mirovyh issledovanij. SPb: Gosudarstvennoe izdatel'stvo, 61-62 (in Russian).

10. Drbal A. (2012). Znamenityj rossijskij i cheshskij astronom Jozef Sikora (1870-1944) [The famous Russian and Czech astronomer Josef Sikora (1870-1944)]. Sovremennye dostizhenija geodezicheskoj nauki i proizvodstva, 2, 20-26 (in Ukrainian).

11. Eremeeva, A. I. (2009). Vasilij Grigor'evich Fesenkov (k 120-letiju so dnja rozhdenija) [Vasiliy Grigoryevich Fesenkov (dedicated to the 120 years since the birth)]. Zemlja $i$ Vselennaja, 4, 52-61 (in Russian).

12. Fesenkov, V. G. (1917). O momente kolichestva dvizhenija Solnechnoj sistemy s tochki zrenija kosmogonicheskoj gipotezy Laplasa [On the moment of momentum of the Solar system from the point of view of the cosmogonic Laplace hypothesis]. Zapiski Har'kovskogo matematicheskogo obshhestva. Serija 2, 15 (5-6), 278-287 s. (in Russian).

13. Shkuratov, Ju. G. (Red.) (2008). 200 let astronomii v Har'kovskom universitete [200 years of astronomy at Kharkiv University]. Har'kov: Har'kovskij nacional'nyj universitet, $632 \mathrm{~s}$. (in Russian).

14. Shumskij, D. L. (1971). Geroj Socialisticheskogo Truda N. P. Barabashov [Hero of Socialist Labor N. P. Barabashov]. Har'kov: Prapor, 136 s. (in Russian).

15. Slastenov, A. I. (1955). Astronomija v Har'kovskom universitete za 150 let (1805-1955) [Astronomy at Kharkov University for 150 years (1805-1955)]. Har'kov: Har'kovskij gosudarstvennyj universitet im. A. M. Gor'kogo, 184 s. (in Russian). 
16. Gosudarstvennyj arhiv Har'kovskoj oblasti [State Archives of the Kharkiv Region] (1938). F.r - 5875. Reg. 1. S. 16. 22 s. (in Russian).

Received 12.07.2020

Received in revised form 27.09.2020

Accepted 01.10.2020

\title{
В. В. Машталір
}

Генеральний штаб Збройних Сил Украӥни, м. Київ, Украӥна

\section{ДІЯЛЬНІСТЬ УКРАЇНСЬКИХ ВІЙСЬКОВО-ІСТОРИЧНИХ МУЗЕЇВ В УМОВАХ ТОТАЛІТАРНОГО РЕЖИМУ}

\author{
E-mail: vadim_mashtalir@ukr.net \\ ORCID: http://orcid.org/0000-0002-8132-217X \\ Web of Science: AAA-4240-2020
}

\begin{abstract}
Анотація. Мета дослідження - проаналізувати в історичному контенті діяльність українських військово-історичних музеїв в умовах тоталітарного режиму у 20-90 роки ХХ століття. Методологія дослідження вибудовувалася на підставі використання сукупності принципів і методів пізнання, застосування яких здійснювалося з опорою на міждисциплінарні підходи до розкриття мети дослідження. Базовими були такі методи історичного пізнання як історико-генетичний, історико-порівняльний, історико-типологічний та історикосистемний, на основі яких опрацьовано наукову та джерельну базу статті. Наукова новизна: на основі широкого кола опублікованих і неопублікованих архівних документів досліджено низку чинників як політичного, соціально-економічного, так і правового характеру функціонування на території України військово-історичних музеїв у визначених хронологічних межах. Досліджено діяльність на території України військово-історичних музеїв у 1920-1990 рр. Висновки. Основним завданням військово-історичних музеїв стало висвітлення та пропагування керівної ролі КПРС, історії радянської армії та флоту, радянського способу життя, досягнень соціалістичного будівництва, формування людини нового типу - будівника комунізму, принципів пролетарського інтернаціоналізму.
\end{abstract}

Ключові слова: воєнно-історичні музеї, музейна мережа, ідеологічні заклади.

\section{V. Mashtalir}

General Staff of the Armed Forces of Ukraine, Kiev, Ukraine

\section{ACTIVITY OF UKRAINIAN MILITARY-HISTORICAL MUSEUMS UNDER A TOTALITARIAN REGIME}

Summary. The purpose of the study is to analyze the historical content of the activities of Ukrainian military history museums under the totalitarian regime at the turn of the $20-90^{\text {s }}$ of the twentieth century. The research methodology was built on the basis of the use of a set of principles and methods of cognition, the application of which was based on interdisciplinary approaches to the disclosure of the purpose of the study. The basic methods of historical cognition were 